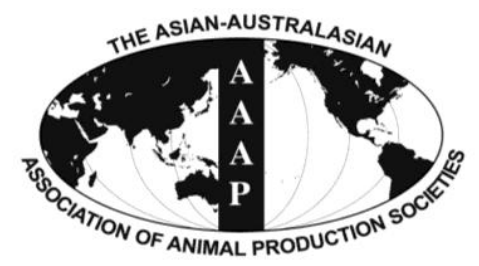

Asian-Aust. J. Anim. Sci.

Vol. 25, No. 4 : 462 - 470

April 2012

www.ajas.info

http://dx.doi.org/10.5713/ajas.2011.11283

\title{
Modeling and Forecasting Livestock Feed Resources in India Using Climate Variables
}

\author{
K. P. Suresh*, G. Ravi Kiran, K. Giridhar and K. T. Sampath \\ National Institute of Animal Nutrition and Physiology, Bangalore 560030, Karnataka, India
}

\begin{abstract}
The availability and efficient use of the feed resources in India are the primary drivers to maximize productivity of Indian livestock. Feed security is vital to the livestock management, extent of use, conservation and productivity enhancement. Assessment and forecasting of livestock feed resources are most important for effective planning and policy making. In the present study, 40 years of data on crop production, land use pattern, rainfall, its deviation from normal, area under crop and yield of crop were collected and modeled to forecast the likely production of feed resources for the next 20 years. The higher order auto-regressive (AR) models were used to develop efficient forecasting models. Use of climatic variables (actual rainfall and its deviation from normal) in combination with non-climatic factors like area under each crop, yield of crop, lag period etc., increased the efficiency of forecasting models. From the best fitting models, the current total dry matter (DM) availability in India was estimated to be 510.6 million tonnes (mt) comprising of $47.2 \mathrm{mt}$ from concentrates, $319.6 \mathrm{mt}$ from crop residues and $143.8 \mathrm{mt}$ from greens. The availability of DM from dry fodder, green fodder and concentrates is forecasted at 409.4, 135.6 and $61.2 \mathrm{mt}$, respectively, for 2030. (Key Words : Feed Resources, Forecasting Models, Auto-Regressive, Climate Variables, DM, Concentrates)
\end{abstract}

\section{INTRODUCTION}

Agriculture is the main occupation in India, and about $60 \%$ of the population is engaged in this activity. The net cultivated area is about 142 million hectares, and livestock rearing is an integral part of the various farming systems, with 304.7 million bovine population and 215.7 million sheep and goats. Arable agriculture contributes a major fodder resource in the form of crop residues, which are extensively fed to the animals. The area under fodder crops amounts to $4.75 \%$ ( 8.9 million hectares) of the total cultivated area. The total area of permanent pastures and grasslands is about 12.8 million hectares. An area of 15.6 million hectares, classified as waste land, is also used for grazing. Forests, and their associated grasslands and fodder trees, are another major source of grazing and fodder collection (Singh et al., 2004; Mishra, 2005).

The animal species raised include the cattle, buffalo, sheep, goats, horses, pigs and poultry, besides some less common species such as yak, camel and mithun. One of the notable characteristics of the Indian livestock sector is that,

\footnotetext{
* Corresponding Author: K. P. Suresh. Tel : +91-080-25711304, Fax : +91-080-25711420, E-mail : sureshkp97@gmail.com Submitted Aug. 17, 2011; Accepted Nov. 30, 2011: Revised Dec. 7, 2011
}

almost its entire feed requirement is met from crop residues and byproducts, grasses, weeds and tree leaves and grazing on common lands and harvested fields (Dikshit and Birthal, 2010). More reliance on crop residues with a low nutrition level does not produce optimum output. Consequently, larger numbers of livestock are kept for producing the required milk, meat and work purposes of their owners. If healthy and well-fed animals are used with improved equipment and processes, India can get increased output from a lesser number of livestock, thus reducing the burden on land (World Bank, 1999; Mishra et al., 2007).

Feed scarcity is the main limiting factor to improving livestock productivity and for example, the actual milk yield of bovines is reported to be 26 to 51 per cent below the attainable yield under field conditions (Birthal and Jha, 2005). Hence, proper assessment and efficient management of available feed resources are vital to improve the productivity of animals and also, the socioeconomic development of the country. It also helps the planners to make appropriate decisions at the right time. The quality of the decision largely depends on the quality of the forecast (De Lurgio and Bhame, 1991; Jain, 1996). The major use of forecasting, as it relates to modeling, is to predict the value of a model's variables as well as the logical relationships of the model at some time in the future. There are three types 
of forecasts: i) short-term (up to one year) forecasts, which are used mainly in deterministic (certainty) models; ii) Intermediate term (one to three years) forecasts; and iii) long-term (beyond three years) forecasts, which are used in both deterministic and probabilistic models. The present paper focuses on modeling and forecasting of livestock feed resources, using probabilistic models such as Autoregressive (AR), to study the influence of climatic and non-climatic variables on the availability of feed resources.

\section{MATERIALS AND METHODS}

\section{Study area and data collection}

The assessment and forecasting of feed resources for livestock was carried out for the entire country. India, the seventh largest country in the world, lies between latitudes $8^{\circ}$ and $37^{\circ} \mathrm{N}$ and longitudes $68^{\circ}$ and $97^{\circ} \mathrm{E}$ and occupies a geographical area of 329 million hectares. The country exhibits great diversity in climate, topography, flora, fauna and land use. The precipitation ranges from $150 \mathrm{~mm}$ in western and north-western desert to about $9,000 \mathrm{~mm}$ in Meghalaya in the north-east. The temperature ranges from sub zero in the Himalayas to about $50^{\circ} \mathrm{C}$ in the central and western parts.

The secondary data on area and production of cereals, pulses, oilseeds, and land use (gross cropped area, acreage under fodder crops, forests, permanent pastures and grazing land, cultural waste land and current fallows) were collected from the Department of Economics and Statistics, Animal Husbandry department, Government of India and Indian Harvest from Center for Monitoring Indian Economy (CMIE) for the period of 1970 to 2010. The data on climate variables (rainfall and its deviation from normal) were collected from CMIE.

\section{Categories of feed resources}

According to Devendra (1997), three major categories of feeds are: i) Pastures and forages - these include native and improved grasses, herbaceous legumes and multipurpose trees ii) Crop residues (dry fodder) - cereal straws, stovers, groundnut haulms etc. iii) Agro-industrial by-products - good examples are cereal bran, coconut cake, palm kernel cake, soya bean, meal, molasses, distillers dried grains. The availability of dry fodder, greens and concentrates was calculated using a suitable extraction ratio, also called as residues to product ratio (RPR). The coefficients used for conversion in the present study are given in Table 1 (Agriculture Statistics at glance, 2008).

The quantum of green fodder, dry fodder and concentrate feed was converted into dry matter (DM) by applying a factor of 0.25 for green fodder, and 0.90 for dry fodder and concentrate feed. The factors for conversion of DM from each source into total digestible nutrients (TDN) were taken as 0.534 for green fodder, 0.476 for dry fodder, and 0.780 for concentrate feed. The factors for conversion of DM from each source into crude protein (CP) were 0.073 , 0.016 and 0.180 for green fodder, dry fodder and concentrate feed, respectively (Dikshit and Birthal, 2010). The major fodder crops like maize, sorghum, pearl millet, Egyptian clover, Lucerne, cluster bean etc., were considered. The area under fodder crops was calculated to be 8.9 million ha, and the fodder productivity was estimated by using the weighted average of 40.93 tonnes/ha, considering the minimum yield of each fodder crop (Hand book of Agriculture, 2005). The weighted average was calculated by using the formula

$$
\bar{x}=\frac{x_{1} w_{1}+x_{2} w_{2}+\ldots+x_{k} w_{k}}{w_{1}+w_{2}+\ldots+w_{k}}
$$

where $\mathrm{x}_{1}, \mathrm{x}_{2} \ldots \mathrm{x}_{\mathrm{k}}$ are yields of different fodder crops and $\mathrm{w}_{1} \mathrm{w}_{2} \ldots \ldots \mathrm{w}_{\mathrm{k}}$ are weights attached to each fodder crop. Weight for each fodder crop is the proportion of area under crop, to the total area under fodder crops.

\section{Statistical analysis}

In order to assess and forecast the feed resources availability for better management of livestock, linear time series models were developed by using Time Series Forecasting System (TSFS) of SAS 9.2 (SAS, 2009). Higher-order auto-regressive (AR) models with lags ranging from 1 to 19 were developed, with climatic and non-climatic factors as regressors. The climatic factors considered in the models were actual rainfall and the deviation of rainfall from normal. The non-climatic factors such as yield, area under crop etc., were also included in the models. Autocorrelation function plot (ACF) was performed to detect the presence of autocorrelation in the data and identify the order of time lag to account for it in modeling. Normalized plots of residuals and plots of standardized versus predicted values were examined as part of diagnostic phase of modeling to assess normality distribution of residuals and homogeneity of variance over the time respectively. The canonical form of full model used for various crop yields is

$$
\begin{aligned}
& \mathrm{Y}_{\mathrm{t}}=\theta_{0}+\phi_{1} \mathrm{Y}_{\mathrm{t}-1}+\phi_{2} \mathrm{Y}_{\mathrm{t}-2}+\phi_{3} \mathrm{Y}_{\mathrm{t}-3}+\ldots \ldots \ldots \\
& \quad+\theta_{1} \text { rainfall }+\theta_{2} \text { rainfall deviation }+\theta_{3} \mathrm{AUC}+\theta_{4} \text { Yield }+\varepsilon
\end{aligned}
$$

Where, $\mathrm{Y}_{\mathrm{t}-11} \mathrm{Y}_{\mathrm{t}-21} \mathrm{Y}_{\mathrm{t}-3 \ldots}$ are past data at time $\mathrm{t}-1, \mathrm{t}-2, \ldots$, $\phi_{1}, \phi_{2}, \phi_{3} \ldots$ and $\theta_{1}, \theta_{2}, \theta_{3} \ldots$ are the co-efficient of autoregressive models, AUC is the Area under crop, Yield is the yield of crop per hectare, and $\varepsilon$ is the error component. The best model was selected based on Root Mean Square Error (RMSE) and Co-efficient of determination $\left(\mathrm{R}^{2}\right)$ values (Box and Jenkins, 1976). 
Table 1. Residues to product ratio (RPR) used in the assessment of livestock feed resources

\begin{tabular}{|c|c|c|c|c|c|}
\hline \multirow[b]{2}{*}{ Category of feed sources } & \multicolumn{5}{|c|}{ Residues to product ratio } \\
\hline & Crop residues & Grains & Bran/hull & Oilcakes & $\begin{array}{l}\text { Green fodder } \\
\text { (t/ha) }\end{array}$ \\
\hline \multicolumn{6}{|l|}{ Straws and stovers } \\
\hline Rice (Oryza sativa) & 1.30 & 0.02 & 0.08 & - & - \\
\hline Wheat (Triticum aestivum) & 1.00 & 0.02 & 0.08 & - & - \\
\hline Bajra (Pennisetum typhoides) & 2.50 & 0.05 & - & - & - \\
\hline Finger millet (Eleusine coracana) & 2.00 & 0.05 & - & - & - \\
\hline Maize (Zea mays) & 2.50 & 0.40 & - & - & - \\
\hline Sorghum (Sorghum bicolor) & 2.50 & 0.05 & - & - & - \\
\hline $\begin{array}{l}\text { Small millets } \\
\text { (Panicum miliare, P. miliaceum, Setaria italic etc.) }\end{array}$ & 2.50 & 0.10 & - & - & - \\
\hline \multicolumn{6}{|l|}{ Tubercrops } \\
\hline Cassava (Mannihot esculenta) & - & $0.12 *$ & - & - & - \\
\hline \multicolumn{6}{|l|}{ Pulses } \\
\hline Gram (Cicer arietinum) & 1.7 & - & 0.03 & - & - \\
\hline Red gram (Cajanus cajan) & 1.7 & - & 0.03 & - & - \\
\hline Other pulses & 1.7 & - & 0.03 & - & - \\
\hline \multicolumn{6}{|l|}{ Oilseeds } \\
\hline Groundnut (Arachis hypogaea) & 2.00 & - & - & 0.60 & - \\
\hline Soya bean (Glycine max) & 1.60 & - & - & 0.73 & - \\
\hline Linseed (Linum usitatissum) & - & - & - & 0.67 & - \\
\hline Rapeseed and mustard (Brassica sps.) & - & - & - & 0.67 & - \\
\hline Sunflower (Helianthus annus) & - & - & - & 0.70 & - \\
\hline Safflower (Carthamus tinctorius) & - & - & - & 0.70 & - \\
\hline Niger seed (Guizotia abyssinica) & - & - & - & 0.72 & - \\
\hline Sesamum (Sesamum usitatissum) & - & - & - & 0.60 & - \\
\hline Coconut (Cocos nucifera) & - & - & - & 0.056 & \\
\hline Cotton (Gossypium sps.) & - & - & - & 0.049 & - \\
\hline Castor (Ricinus communis) & - & - & - & 0.50 & - \\
\hline \multicolumn{6}{|l|}{ Greens } \\
\hline Sugarcane (Saccharum officinalis) & - & - & - & - & $0.25 * *$ \\
\hline $\begin{array}{l}\text { Gross cropped area, excluding the area } \\
\text { under fodder crops }(2.024 \% \text { of gross cropped area) }\end{array}$ & - & - & - & - & 5.0 \\
\hline Area under fodder crops & - & - & - & - & $40.93 * * *$ \\
\hline Forest area & - & - & - & - & 1.50 \\
\hline Permanent pastures and grazing land & - & - & - & - & 5.00 \\
\hline Land under misc. tree crops and groves not included & - & - & - & - & 1.00 \\
\hline Cultural wasteland & - & - & - & - & 1.00 \\
\hline Current fallow & - & - & - & - & 1.00 \\
\hline Other fallow & - & - & - & - & 1.00 \\
\hline
\end{tabular}

Source: Agricultural statistics at a glance, 2007, Directorate of economics and statistics, Ministry of Agriculture, GOI.

* Srinivas, T. and M. Anantharaman. (2005). ** Sugarcane top to cane ratio.

*** Weighted average estimated from the yields as per Hand Book of Agriculture, 2005. 


\section{RESULTS AND DISCUSSION}

\section{Best fitting models}

The data on production of 23 crops for 40 years, along with climatic and non-climatic factors were used to develop the time series forecasting models. The best fitting models were assessed based on minimum value of RMSE, and the maximum value of $\mathrm{R}^{2}$. Two climatic factors i.e., actual rainfall, and its deviation from normal were used in the models. The non-climatic variables such as temporal factors (trend, seasonality, cyclical and other fluctuations), lag period (serial correlation or successive dependence of data), area under crop, and crop yield (to account for the improvement in management practices and technology) were also considered in the model development. The time lag period was maximum (19 years) for sunflower, and minimum (one year) for cassava. The climatic and non-climatic factors were significant $(\mathrm{p}<0.05)$ for most of the crops. The characteristics of higher order autoregressive models with different time lag periods to account for the variation due to serial correlation, and other variables for different crops are given in Table 2, and depicted in Figure 1.
The best fitting models for different types of land use pattern (Table 3, Figure 1) were: linear trend for gross cropped area; linear (Holt) exponential smoothing for the land uses like forest, permanent pastures and grazing; log linear (Holt) exponential smoothing for the area under miscellaneous tree crops and groves; higher order autoregressive for current fallows, other fallows and the area under fodder crops. Actual rainfall and its deviation from normal were significant $(p<0.05)$ for both types of fallows, and the area under fodder crops.

The auto-regressive models are more efficient than simple linear regression models for longitudinal data. To exploit the cross-sectional and temporal attributes of data sets, auto-regressive models were developed for each crop. This method is appropriate for longitudinal data (Pinheiro and Bates, 2000; Zuur et al., 2009), where observations within a group are more often similar, than when predicted on a pooled data basis. The simple linear regression ignores the grouping effect and violates the assumption of independence of observations. In a similar type of study in Tanzania, Pedram Rowhani et al. (2011) relied only on the first order autoregressive models to capture the serial correlation structure. However, in the present work, time lag

Table 2. Summary of Autoregressive forecasting models for crop production with various regressors

\begin{tabular}{|c|c|c|c|c|c|c|c|c|}
\hline Sl no. & Crop & $\begin{array}{l}\text { Lag period in } \\
\text { autoregressive } \\
\text { models }\end{array}$ & $\begin{array}{l}\text { Actual } \\
\text { rainfall }\end{array}$ & $\begin{array}{c}\text { Rainfall } \\
\text { deviation from } \\
\text { normal }\end{array}$ & $\begin{array}{l}\text { Area under } \\
\quad \text { crop }\end{array}$ & Yield & $\mathrm{R}^{2}(\%)$ & RMSE \\
\hline 1 & Rice & 10 & $0.097+$ & $0.091+$ & $<0.001 * *$ & $<0.001 * *$ & 99.9 & 0.434 \\
\hline 2 & Wheat & 5 & 0.586 & 0.910 & $<0.00 * *$ & $<0.001 * *$ & 99.9 & 0.649 \\
\hline 3 & Bajra & 3 & 0.734 & 0.343 & $<0.001 * *$ & $<0.001 * *$ & 99.4 & 0.146 \\
\hline 4 & Sorghum & 9 & 0.273 & 0.301 & $<0.001 * *$ & $<0.001 * *$ & 98.3 & 0.249 \\
\hline 5 & Finger millet & 5 & 0.232 & $0.069+$ & $<0.001 * *$ & $<0.001 * *$ & 96.7 & 0.067 \\
\hline 6 & Small millets & 10 & 0.121 & $0.056+$ & $<0.001 * *$ & $<0.001 * *$ & 99.3 & 0.042 \\
\hline 7 & Maize & 9 & 0.489 & 0.616 & $<0.001 * *$ & $<0.001 * *$ & 99.7 & 0.208 \\
\hline 8 & Bengal gram & 14 & 0.421 & $0.002 * *$ & $<0.001 * *$ & $<0.001 * *$ & 99.8 & 0.039 \\
\hline 9 & Red gram & 5 & 0.822 & $0.077+$ & $<0.001 * *$ & $<0.001 * *$ & 99.6 & 0.023 \\
\hline 10 & Other pulses & 14 & 0.246 & $0.012 *$ & $<0.001 * *$ & $<0.001 * *$ & 99.9 & 0.027 \\
\hline 11 & Groundnut & 17 & 0.560 & 0.173 & $<0.001 * *$ & $<0.001 * *$ & 99.8 & 0.068 \\
\hline 12 & Soyabean & - & - & - & - & - & 94.4 & 0.801 \\
\hline 13 & Linseed & 6 & 0.117 & 0.168 & $<0.001 * *$ & - & 93.5 & 0.032 \\
\hline 14 & Rapeseed and mustard & 14 & $0.001 * *$ & $0.003 * *$ & $<0.001 * *$ & $<0.001 * *$ & 99.5 & 0.138 \\
\hline 15 & Sunflower & 19 & $<0.001 * *$ & $<0.001 * *$ & $<0.01 * *$ & $<0.001 * *$ & 99.3 & 0.037 \\
\hline 16 & Safflower & 17 & $<0.001 * *$ & $<0.001 * *$ & $<0.01 * *$ & $<0.001 * *$ & 99.1 & 0.011 \\
\hline 17 & Nigerseed & 16 & 0.337 & 0.703 & $<0.001 * *$ & $<0.001 * *$ & 99.6 & 0.002 \\
\hline 18 & Sesamum & 10 & 0.948 & 0.988 & $<0.001 * *$ & $<0.001 * *$ & 99.0 & 0.011 \\
\hline 19 & Sugarcane & 10 & 0.555 & 0.305 & $<0.001 * *$ & $<0.001 * *$ & 99.9 & 2.04 \\
\hline 20 & Coconut & 13 & 0.670 & 0.656 & $<0.001 * *$ & $<0.001 * *$ & 99.8 & 1.31 \\
\hline 21 & Cassava & 1 & 0.728 & 0.375 & $<0.001 * *$ & $<0.001 * *$ & 99.9 & 49.72 \\
\hline 22 & Cotton & 12 & $<0.001 * *$ & $<0.001 * *$ & $<0.001 * *$ & $<0.001 * *$ & 99.8 & 0.206 \\
\hline 23 & Castor & 12 & 0.166 & 0.164 & $<0.001 * *$ & $<0.001 * *$ & 99.9 & 0.025 \\
\hline
\end{tabular}

Data of previous 40 years, 1970-2010, used to construct models; $\mathrm{R}^{2}$, Co-efficient of determination; RMSE = Root mean square error.

+ Suggestive of significance, $*$ and $* *$ Significance at $5 \%$ and $1 \%$ respectively. 

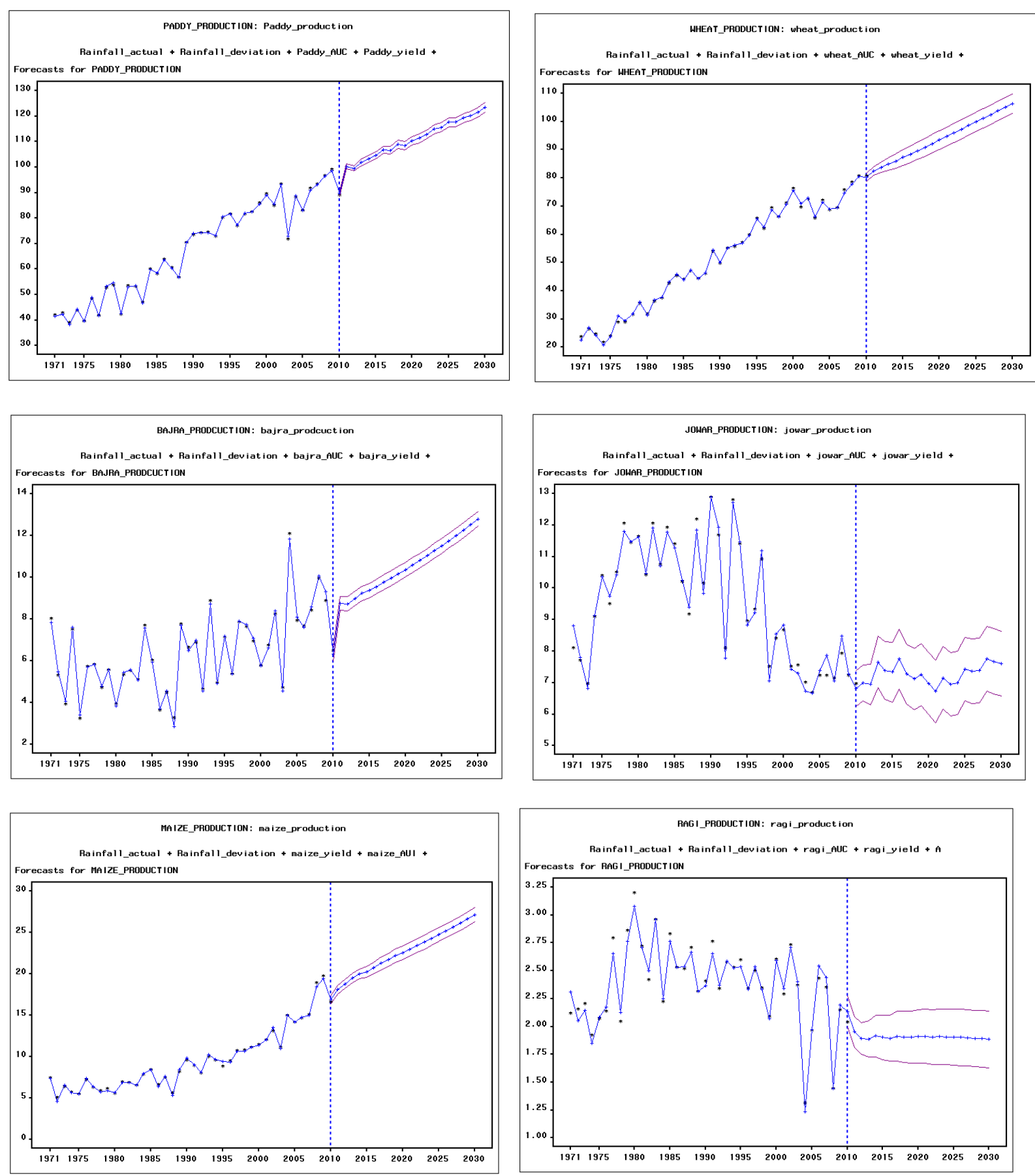

Figure 1. Graphs showing the best fitted auto-regressive models for forecasting crop production till 2030 (Selected crops).

period was extended further back till the complete capture of the serial correlation structure, and hence, these well developed models are more efficient for prediction of feed resources.

Two climatic factors, actual rainfall, and its deviation from normal, were used as regressors in the auto-regressive models. Both were significant $(\mathrm{p}<0.05)$ for most of the oilseeds (sunflower, safflower, cotton and rapeseed \& mustard) and pulse crops like Bengal gram. These factors, though not statistically significant for the remaining crops, have very low probability (p) value, indicating their potential contribution in the models. Hence, the autoregressive models obtained are more efficient when rainfall variability is included for forecasting feed resources. Several studies have shown that change in climatic parameters affects the agricultural production. Droughts, floods, heavy precipitation events and heat waves are known to negatively impact agricultural production (Naresh Kumar et al., 2011). Fluctuations in rainfall have widespread effects on each stage of crop management, 

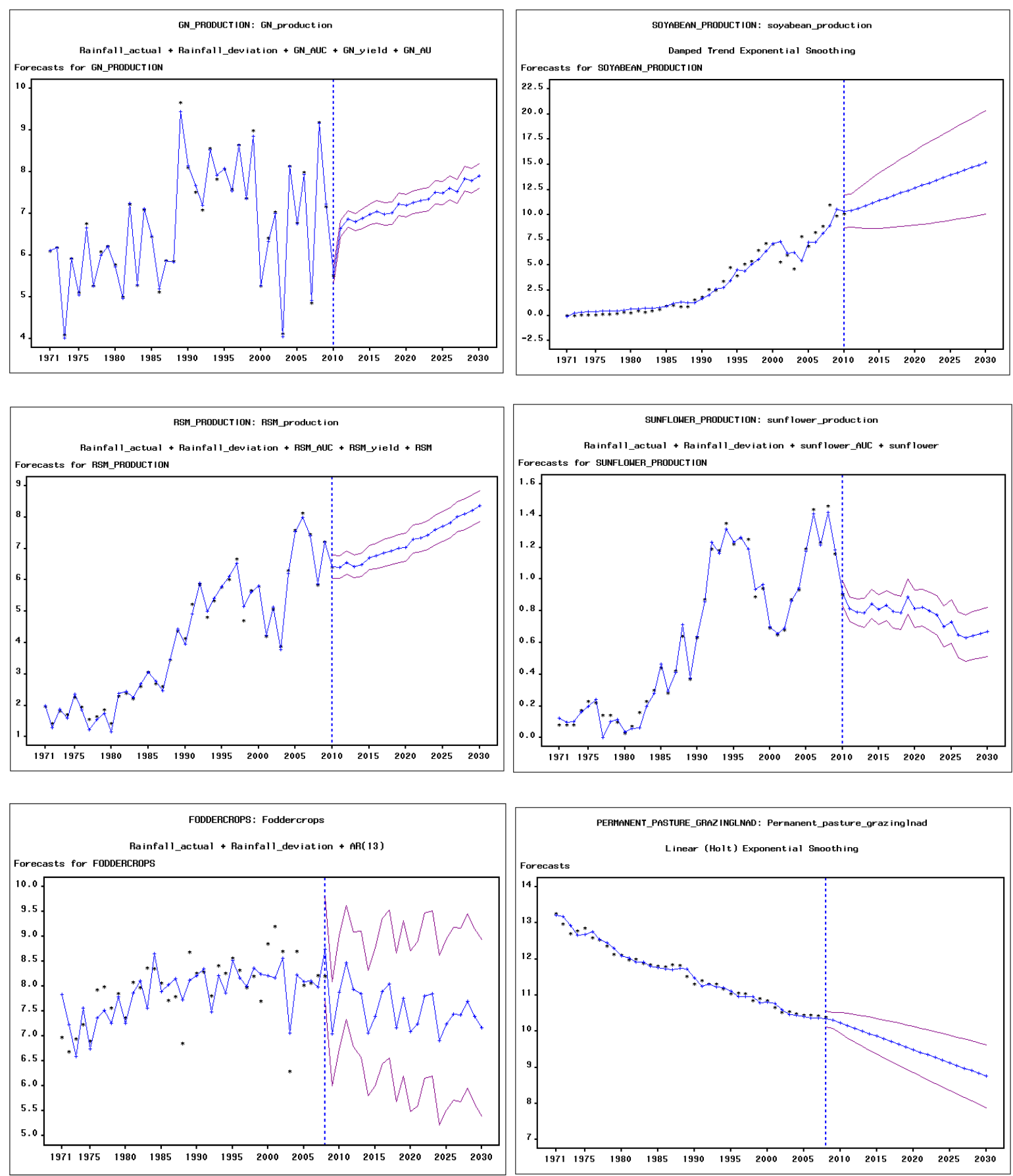

Figure 1. Graphs showing the best fitted auto-regressive models for forecasting crop production till 2030 (Selected crops). (Continued)

starting from seedbed preparation until harvest (Hollinger, 1994). The non-climatic factors, such as, area under crop and yield of crop were also studied for their effect by using the auto-regressive models. These factors are significant $(p<0.001)$ across all the crops, and inclusion of them enhanced the predictive efficiency of models. This empirical study is first of its kind to document effects of climatic and non-climatic factors on livestock feed resources avaiablity in India.

Significance of non-climatic factors in the auto- regressive models indicate the variablity associated with change in managemental practices and/or technological progress in agriculture over the years. Most of the previous studies either used time as the only factor to represent temporal changes, or, climatic factors along with time, in developing the models (Wheeler et al., 2000; Challinor et al., 2005; Porter and Semenov, 2005; Pedram Rowhani et al., 2011). The present study attempts to capture the variation due to these factors in the model building. Failure to allow these specific characteristics may result in inferior 
Table 3. Summary statistics for forecasting pattern of land use

\begin{tabular}{|c|c|c|c|c|c|c|}
\hline $\begin{array}{l}\text { Sl } \\
\text { no. }\end{array}$ & Land use & Model used & $\begin{array}{l}\text { Actual } \\
\text { Rainfall }\end{array}$ & $\begin{array}{c}\text { Rainfall } \\
\text { deviation } \\
\text { from normal }\end{array}$ & $\mathrm{R}^{2}(\%)$ & RMSE \\
\hline 1 & $\begin{array}{l}\text { Gross area grown excluding area under } \\
\text { fodder crops }\end{array}$ & Linear trend & - & - & 83.9 & 3.76 \\
\hline 2 & Area under fodder crops & Autoregressive with 13 lag periods & 0.927 & 0.377 & 52.0 & 0.442 \\
\hline 3 & Forest area & Linear Holt Exp smoothing & - & - & 95.3 & 0.330 \\
\hline 4 & Permanent pastures and grazing land & $\begin{array}{l}\text { Linear (Holt) Exponential } \\
\text { smoothing }\end{array}$ & - & - & 98.3 & 0.106 \\
\hline 5 & $\begin{array}{l}\text { Land under misc. tree crops and groves } \\
\text { not included }\end{array}$ & $\begin{array}{l}\text { Log linear (Holt) exponential } \\
\text { smoothing }\end{array}$ & - & - & 72.4 & 0.137 \\
\hline 6 & Cultural wasteland & $\begin{array}{l}\text { Damped trend exponential } \\
\text { smoothing }\end{array}$ & - & - & 97.9 & 0.219 \\
\hline 7 & Current fallow & Autoregressive with 13 lag periods & 0.271 & $0.002 * *$ & 60.0 & 1.256 \\
\hline 8 & Other fallow & Autoregressive with 10 lag periods & $0.080+$ & $0.019^{*}$ & 75.7 & 0.336 \\
\hline
\end{tabular}

Data of previous 40 years, 1970-2010, used to construct models; $\mathrm{R}^{2}$, Co-efficient of determination; RMSE = Root mean square error.

+ Suggestive of significance, $*$ and $* *$ Significance at $5 \%$ and $1 \%$ respectively.

forecast of aspects of interest, and results in inaccurate estimates of feed resource availability.

\section{Assessment of feed resources}

Assessment of livestock feed resources is the main focus of this study. The standard conversion factors like straw to grain ratio, cake to grain ratio etc were used to estimate the availability of dry fodder and concentrates (Table 1). The straw/stover to grain ratio for cereals varied between 1 and 2.5. Among cereal grains, the proportion used for feed purposes is maximum for maize (40\%) and minimum for rice and wheat (2\%). In case of Cassava, $12 \%$ of tuber production is used for livestock feed (Srinivas and Anantharaman, 2005). Pulse husks or legume hulls, a by-product of pulse milling industries is a source of animal feed and $3 \%$ of pulse production contributes to husk. Among the oilseed cakes, the contribution from soya bean is the maximum (73\%). For sugarcane, $25 \%$ of cane production is considered in the calculation of greens. Among various other sources of green fodder, the productivity varied between one to 40.93 tons per hectare.

The standard conversion factors like straw to grain ratio, cake to grain ratio etc., were used to estimate the availability of dry fodder and concentrates. In some of the earlier studies (e.g., Ramachandra et al., 2007), similar conversion factors were used for estimating the availability of feed resources. The contribution from cassava is included in the present study, as the byproducts obtained during flour extraction from cassava are being widely used as cattle feed. The area under fodder crops has marginally increased from 6.9 million hectares in 1970 to 8.9 million hectares in 2011. The conversion factors used for estimating fodder crop yields were obtained by using the weighted average method, taking into consideration, yield and area under different fodder crops (Hand Book of Agriculture, 2005), with an average yield of 40.93 tonnes/ha. Ramachandra et al. (2007) estimated the greens availability from fodder crops by assuming that $4 \%$ of gross cropped area is under fodder crops. In a study by Jain and Shivatar singh (1990), the availability of feed resources was quantified by merely assuming the conversion factors for crop residues and greens. The inclusion of fodder crops and cassava has increased the total feed resources availability by $80 \mathrm{mt}$ in the present study.

There is a decreasing trend in the forest area, permanent pastures and grazing land, land under miscellaneous tree crops, cultural waste land and fallows and it has a greater negative impact on the dry matter availability from greens. Natural pastures are most commonly utilized feed resources in India and contribute significant amount of feed. However, the contribution and productivity of pasture lands is declining with time, mainly due to their diversion for other purposes, and thus reducing the total feed resources availability for livestock (Misra et al., 2007).

\section{Forecasting of feed resources}

Forecasting of feed resources is the third important aspect, after modeling and assessment as forecasts are useful to policy makers for contingency planning in the country. Feed resources availability from dry fodder, greens and concentrates were forecasted by using best fitted models developed for this purpose. Forecasting up to 2030 was done in this study (Table 4, Figure 1). The availability of dry fodder from crop residues increased from $160.8 \mathrm{mt}$ in 1970 to $296.2 \mathrm{mt}$ in 2010 , and is predicted to jump further to $409.4 \mathrm{mt}$ by 2030 . Similarly, the production of 
Table 4. Assessment and forecasting the livestock feed resources in India on dry matter basis (in million tons)

\begin{tabular}{|c|c|c|c|c|c|c|c|c|c|c|c|c|c|c|}
\hline Feed $\mathrm{r}$ & 1970 & 1980 & 1990 & 2000 & 2005 & 2010 & 2011 & 2012 & 2013 & 2014 & 2015 & 2020 & 2025 & 2030 \\
\hline ry fodder & 160.8 & 1598 & 240.5 & 278.5 & 272.1 & 296.2 & 319.6 & 322.4 & 329.7 & 334.3 & 338.4 & 360.2 & 385.7 & 409.4 \\
\hline Dic & 3.5 & 0.3 & 0.9 & 40.1 & 42.3 & 44.8 & 47.2 & 70.1 & 48.8 & 49.5 & 50.2 & 53.6 & 57.4 & 61.2 \\
\hline Greens & 120.6 & 25.1 & 137.2 & 146.9 & 135.7 & 136.7 & 143.8 & 139.1 & 138.1 & 131.1 & 134.9 & 133.1 & 135.4 & 135.6 \\
\hline Total DM & 299.9 & 303.2 & 408.6 & 465.5 & 450.1 & 477.7 & 510.6 & 509.6 & 516.6 & 514.9 & 523.5 & 546.9 & 578.5 & 606.2 \\
\hline TDN & 155.4 & 157.1 & 211.8 & 242.3 & 235.0 & 248.9 & 265.7 & 265.3 & 268.7 & 267.7 & 272.3 & 284.3 & 300.7 & 315.0 \\
\hline DCP & 14.7 & 15.0 & 19.4 & 22.4 & 21.9 & 22.8 & 24.1 & 24.0 & 24.1 & 23.8 & 24.3 & 25.1 & 26.4 & 27.5 \\
\hline
\end{tabular}

$\mathrm{DM}=$ Dry matter; $\mathrm{TDN}=$ Total digestible nutrients; $\mathrm{DCP}=$ Digestible crude protein.

concentrates increased from just $18.5 \mathrm{mt}$ in 1970 to $44.8 \mathrm{mt}$ in 2010. By 2030, it is forecasted to be $61.2 \mathrm{mt}$. The availability of greens improved from $120.6 \mathrm{mt}$ in 1970 to $136.7 \mathrm{mt}$ in 2010 , and is forecasted for a modest decrease to $135.6 \mathrm{mt}$ by 2030 .

The total available dry matter in the country increased from $299.9 \mathrm{mt}$ in 1970 to $477.7 \mathrm{mt}$ at present. During the last 40 years, the availability of total DM, concentrates, crop residues and greens increased by $59 \%, 142 \%, 84 \%$ and $13 \%$, respectively. The current availability of TDN and DCP in the country is estimated to be $248.9 \mathrm{mt}$ and $22.8 \mathrm{mt}$, respectively, and it is forecasted that their availability will be $315.0 \mathrm{mt}$ and $27.5 \mathrm{mt}$, respectively, by 2030 .

Timely forecasting of national animal feed resources is very important for planners and policy makers, as the actual assessment based on the crop production data for any given year is available only after a lapse of 10 to 14 months. Better forecasting provides the right information at right time. In a report, Ramachandra et al. (2007) assessed the feed availability retrospectively though such information will be of limited practical utility. Current and prospective information on feed resources availability is more important for contingency planning. Additionally, the feed resources are more affected by seasonality and other factors such as difficulty in handling and storing crop residues, pest infestation, molding and fire risk (Hilmersen et al., 1984; Owen and Aboud, 1988). The combination of seasonality and storage problems creates an annual cycle of brief peaks in crop residue availability, followed by periods of scarcity. Hence, forecasting of feed resources availability is essential for a country like India to plan properly for exigencies like severe shortage of feed resources.

Ramachandra et al. (2007) projected the availability of dry fodder, concentrates and green fodder at 417, 44 and $138 \mathrm{mt}$, respectively, by 2020. However, the methodology adopted for this projection is not clear with respect to data set and models used. In the present study, the corresponding figures for the availability of dry fodder, concentrates and green fodder are 360.2, 53.6 and $133.1 \mathrm{mt}$, respectively. The higher estimates for green fodder in this study are due to the inclusion of the contribution from sugarcane tops and also, the fodder crops. The estimates in this study are better, as they are worked out based on auto-regressive models, using climatic and non-climatic variables.

\section{Limitation}

This study estimated the feed resources availability based on residue to product ratios. A single conversion factor was used for each crop, which does not account for the varietal differences within the crop. Data on varietyspecific conversion ratios and variety-wise acreage under each crop are not available. Similarly, the burning of rice and wheat straws in North India is not quantified and to that extent, the quantities of dry fodder availability from these two crops are overestimated. Precise data on amount straw diverted towards the packaging industry is not available and hence, that shortfall is not accounted for. The quantity of grains, especially maize, diverted towards the ethanol industry is also not considered due to non-availability of authentic data. Data in respect of unconventional feed resources such as Madhuca longifolia (mahua) cake, Pongamia pinnata (karanj) cake, kitchen waste etc. is not available, and hence, not included in the estimation of feed resources. To that extent, feed resources availability is underestimated.

\section{CONCLUSION}

The availability of crop residues, greens and concentrate in India for the next 20 years was forecasted by using autoregressive models, based on 40 years of historical data on crop production and land use patterns. Use of climatic and non-climatic variables in the models resulted in an improved estimation of feed resources. Forecasting of feed resources is essential to ensure better preparedness for dealing with shortage of livestock feeds caused by abnormal weather events. By analyzing the impact of previous climatic and non-climatic aberrations on the feed resources, future or near-term scenarios of availability can be forecasted. They help the decision makers to implement adaptation strategies to ensure sustainable livestock production. These models can also be used for forecasting the agricultural production in the country. 


\section{ACKNOWLEDGEMENTS}

Authors express their gratitude to Dr. R. Bhatta for constructive suggestions in preparation of the manuscript, and Dr. S. Anandan, for providing the technical help for assessing the feed resources.

\section{REFERENCES}

Birthal, P. S. and A. K. Jha. 2005. Economic losses due to various constraints in dairy production in India. Indian J. Anim. Sci. 75:1476-1480.

Box, G. E. P. and G. M. Jenkins. 1976. Time series analysis: Forecasting and control. Oakland, California. Holden-day.

Carter, T. R. and M. L. Parry. 1986. 'Climatic changes and yield variability', (Ed. P. B. R. Hazell). Summary proceedings of a workshop on cereal yield variability, International Food Policy Research Institute, Washington, DC. pp. 47-68.

Challinor, A., T. Wheeler, P. Craufurd and J. Slingo. 2005. Simulation of the impact of high temperature stress on annual crop yields. Agric. Forest Meteorol. 135:180-189.

DeLurgio, S. and C. Bhame. 1991. Forecasting systems for management. Homewood, IL, Irwin.

Devendra, C. 1997. Crop residues for feeding animals in Asia: technology assessment and adoption. In: Crop Residues in Sustainable Crop Llivestock Farming systems (Ed. C. Renard). Commonwealth Agricultural Bureau, Wallingford, UK. pp. 2428.

Dikshit, A. K. and P. S. Birthal. 2010. India's livestock feed demand: Estimates and projections. Agricultural Economics Research Review. pp. 23:15-28.

Government of India. 2008. Agricultural statistics at a glance. Ministry of Agriculture, New Delhi.

Government of India. 2009. Year-wise Area under crops, production - All India. http://dacnet.nic.in

Hand Book of Agriculture. 2005. ICAR, Ministry of Agriculture, Government of India, New Delhi.

Hilmersen, A., F. Dolberg and O. Kjus. 1984. Handling and storing. In: Straw and Other Fibrous By-products as Feed (Ed. F. Sundsttel and E. Owen). Elsevier, Amsterdam, The Netherlands, pp. 25-44.

Hollinger, S. E. 1994. Future direction and needs in agricultural meteorology-climatology and modeling. Agric. Forest Meteorol. 69:1-7.

Jain, C. L. 1996. Monthly corporate forecasts Meeting. J. Bus. Forecast. Methods Syst. 15:2-28.

Jain, P. K. and Shivatar Singh. 1990. Quantitative and qualitative insufficiency of livestock feeds by $2001 \mathrm{AD}$ and possibilities of bridging gap. Indian J. Anim. Sci. 60:1224-1229.

Linda, O. Mearns, C. Rosenzweig and Richard Goldberg. 1997. Mean and variance change in climate scenarios: Methods, agricultural applications and Measures of uncertainty. Clim. Change 35:367-396.

Lobell, D. B. and C. B. Field. 2007. Global scale climate-crop yield relationships and the impacts of recent warming. Environ. Res. Lett. 2:014002.
Misra, A. K. 2005. Contingency planning for feeding and management of livestock during drought. In: Drought Management (Ed. K. D. Sharma and K. S. Ramasastri). Allied Publishers Pvt. Ltd., New Delhi. pp. 276-286.

Misra, A. K., C. V. Rama Rao, K. V. Subrahmanyam, M. Vijay Sankar Babu, B. Shivarudrappa and Y. S. Ramakrishna. 2007. Strategies for livestock development in rainfed agro-ecosystem of India. Livest. Res. Rural Dev. 19:83.

Naresh Kumar, S., P. K. Aggarwal, S. Rani, S. Jain, R. Saxena and N. Chauhan. 2011. Impact of climate change on crop productivity in Western Ghats, coastal and northeastern regions of India. Curr. Sci. 101:1-10.

Owen, E. and A. A. O. Aboud. 1988. Practical problems of feeding crop residues. In: Plant Breeding and the Nutritive Value of Crop Residues Proceedings of an International Workshop, 7-10 December, 1987

Parry, M. L. and T. R. Carter. 1985. 'The Effect of Climatic variations on Agricultural Risk', Clim. Change 7:95-110.

Pedram Rowhani, David B Lobell, Marc Linderman and Navin Ramakutty. 2011. Climate variability and crop production in Tanzania. Agric. Forest Meterol. 151:449-460.

Pinheiro, J. C. and D. M. Bates. 2000. Mixed effect models in S and S-plus . Springer, Newyork.

Porter, J. R. and M. A. Semenov. 2005. Crop responses to climatic variation. Philos. Trans. R. Soc. Lond. Ser. B: Biol. Sci. 360: 2021-2035

Ramachandra, K. S., V. K. Taneja, K. T. Sampath, S. Anandan and U. B. Angadi. 2007. Livestock feed resources in different agroecosystems of India: Availability, requirement and their management. National Institute of Animal Nutrition and Physiology, Bangalore, India.

SAS. 2009. SAS Institute Inc, Cary, NC, USA.

Singh, H. P., K. D. Sharma, G. S. Reddy and K. L. Sharma. 2004. Dryland agriculture in India. In: Challenges and strategies for dryland agriculture. CSSA Special Publication no. 32. Madison, USA. pp. 67-92.

Singh, K., G. Habib, M. M. Siddiqui and M. N. M. Ibrahim. 1997. Dynamics of feed resources in mixed farming systems of South Asia. In: Crop Residues in Sustainable Mixed Crop/Livestock Farming Systems (Ed. C. Renard). CAB International, Wallingford, UK/ICRISAT (International Crops Research Institute for the Semi- Arid Tropics), Patancheru, India/ILRI (International Livestock Research Institute), Nairobi, Kenya. pp. 113-130.

Srinivas, T. and M. Anantharaman. 2005. Cassava marketing system in India. Technical bulletin, 43. Central tuber crops research institute, Thiruvananthapuram, India.

Wheeler, T., P. Craufurd, R. Ellis, J. Porter and P. Vara Prasad. 2000. Temperature variability and the yield of annual crops. Agric. Ecosyst. Environ. 82:159-167.

World Bank. 1999. India: Livestock Sector review: Enhancing growth and development. The World Bank and Allied Publishers: New Delhi.

Zuur, A. F., E. N. Ieno, N. Walker, A. A. Saveliev and G. M. Smith. 2009. Mixed effects models and extensions in ecology with $R$ (Statistics for Biology and Health). Springer. 